\title{
Drawdown and Dynamics of Groundwater Table in Kathmandu Valley, Nepal
}

\author{
Dipendra Gautam ${ }^{1, *}$ and Raghu N. Prajapati ${ }^{2}$ \\ ${ }^{I}$ Center for Postgraduate Studies, Nepal Engineering College, Pokhara University, Nepal \\ ${ }^{2}$ Department of Civil Engineering, Nepal Engineering College, Pokhara University, Nepal
}

\begin{abstract}
Groundwater resources in Kathmandu valley provide water for human consumption, industry, hotels and agriculture as well. Rapid urbanization, mushroomed increment in the built up area, overexploitation of surface and groundwater resource, removal of vegetation cover, change in land use pattern, and formation of impervious surface have led the ultimate lowering of groundwater table and minimization of groundwater recharge as well. This study quantifies the drawdown rate along with the groundwater dynamics across the Kathmandu valley, as the valley constitutes mostly of the urban population of Nepal including the capital city. In Kathmandu valley, for domestic purpose as well as the industrial purpose, water has been pumped continuously surpassing the natural recharge. The groundwater table drawdown has been estimated based on the recorded data of average static groundwater table depth and was found to be $0.7249 \mathrm{~m}$ in average and linear regression model of drawdown has been depicted along with the associated range of standard deviation. This drawdown has close proximity with the Mexico City alluvial deposit where ground subsidence is nowadays noticeably occurring. Similar land subsidence, water pollution and scarcity of water would be the near future consequence in Kathmandu valley as nearly $50 \%$ of valley population relies on groundwater resources. Similarly, the groundwater dynamics study has shown the shifting of drainage towards southwestern part of Kathmandu valley. Thus Kathmandu valley is in dire need of proper groundwater management execution in order to avoid the hydrological, hydro-geological and environmental impacts of rapid drawdown.
\end{abstract}

Keywords: Draw down rate, dynamics of flow, groundwater table, Kathmandu valley, overexploitation, urbanization.

\section{INTRODUCTION}

Higher population growth and rapid urbanization in the third world has exerted alarming pressure over groundwater not only for drinking purpose and domestic use rather agricultural, and industrial use are more common nowadays. Among the ancient civilizations of South Asia, Kathmandu valley has been developed as a settlement largely depending upon groundwater for centuries as the potential surface water resources are scarce or polluted. Due to alarming situation of drawdown and enhanced scarcity of water, necessity of delineating the groundwater dynamics and the drawdown rate has been felt in recent years so as to accommodate the mushroomed population of the capital city. However, it is obvious that the groundwater dynamics and drawdown depiction may lead to imply some visible efforts on lowering the pressure over groundwater. Derivation of governing equation for drawdown and illustration of groundwater dynamics may reflect hydro-meteorological conditions [1] notifying particularly dominant water source [2]. The groundwater of Kathmandu valley is under immense pressure [3] as it is being heavily used for domestic as well as industrial purposes that require water, resulting in a decline of its water level.

*Address correspondence to this author at the Center for Postgraduate Studies, Nepal Engineering College, Pokhara University, Nepal;

Tel: +977-9851139815; Fax: 977-1-6611681; E-mail: strdyn@yahoo.com
The study of Metcalf and Eddy (2000) [4] delineated a drawdown in pumping water level from $9 \mathrm{~m}$ to as $68 \mathrm{~m}$ in Kathmandu valley in the late 1990s, this directly links the overpopulation, rapid urbanization, growing trend of concrete constructions, removal of vegetation cover, increased number of hotels and brick factories and degradation of recharge areas, among others. The total sustainable withdrawal of groundwater from the valley's aquifers is approximately 26.3 MLD [5] but the total groundwater currently extracted is about 58.6 MLD [4]. Recharge quantity in Kathmandu valley aquifer has been variously reported to be 15 million $\mathrm{m}^{3} / \mathrm{yr}$ (i.e. $165 \mathrm{~mm} / \mathrm{yr}$ ) [6] to less than 5 million $\mathrm{m}^{3} / \mathrm{yr}$ (i.e. 55 $\mathrm{mm} / \mathrm{yr}$ ) [7], however it is not as predicted in recent dates because most of the annual precipitation is discharged as surface water. The study conducted in 2010 shows the extraction of groundwater in 1970s about 0.04 million m $3 / \mathrm{yr}$ reaching up to 12.2 million $\mathrm{m}^{3} / \mathrm{yr}$ in $1980 \mathrm{~s}$ and another $90 \%$ increase in 1990s [8,9]. The rate of abstraction in Kathmandu valley far exceeds the rate of recharge at around 20 times and the groundwater resources are predicted to be depleted in less than 100 years [10]; moreover the limiting groundwater abstraction is designated as 40.1 MLD for Kathmandu valley but present abstraction status is nearly 60 MLD as predicted in 1992 [11], and this must have increased in greater extent till date. The vegetation cover guides the runoff, evapotranspiration and infiltration in greater extent [12], though Kathmandu valley topsoil is nowadays almost impervious 


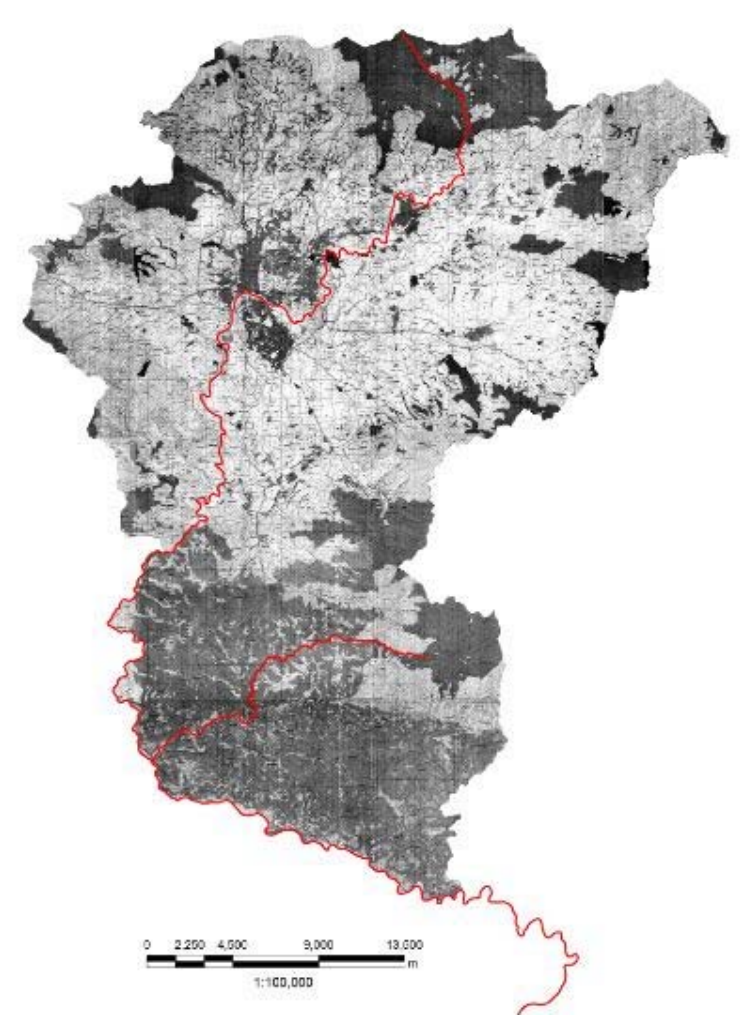

Fig. (2.1). Drainage map of Kathmandu valley with the major Bagmati River highlighted.

with very little vegetation covering thus preventing the infiltration and contribution in groundwater.

Regular monitoring mechanisms and researches in Kathmandu valley groundwater depletion have been seldom conducted, however the discharge depletion in almost all of the stone spouts, drag wells suggest the alarming situation. As there is no regular monitoring mechanism, reliable and sufficient data are not available for formulation of exact drawdown pattern. The rate of drawdown of groundwater in Kathmandu valley is non-uniform, because groundwater abstraction, rate of urbanization, anthropogenic activities, land use change, vegetation cover, distribution of hotels and factories are not uniform among the three groundwater districts of Kathmandu valley. Beside this, the exact groundwater abstraction is not clearly delineated yet, because there's no any control and monitoring mechanism. Sufficient attention towards management of groundwater resources has not been paid yet, so unrestricted abstraction could be seen across the valley. In addition to this, Kathmandu valley groundwater drawdown hasn't been monitored regularly so as to delineate a proper drawdown model; so this study attempts to quantify an annual drawdown pattern and dynamics in terms of discharge accumulation. Without acquiring sufficient and significant hydrological and hydro-geological database, it wouldn't be rational to develop a hydrological model, so for a poor database area with very few observations, as a preliminary tool for estimating the groundwater table depth, a regression model has been formulated.

This paper specifically aims to identify:
- Linear drawdown regression model for estimating the groundwater table depth;

- Represent the yearly groundwater dynamics through the discharge points;

The outcomes of this research could be valuable in groundwater resource planning and management in the study area.

\section{STUDY AREA}

Kathmandu valley is an oval shaped intermontane valley of about $899 \mathrm{~km}^{2}$ area; situated in the lesser Himalaya of Central Nepal (Fig. 2.1), stretching $30 \mathrm{~km}$ towards East-West and $25 \mathrm{~km}$ towards North-South. The valley is situated between $27^{\circ} 32^{\prime} \mathrm{N}$ to $27^{\circ} 49^{\prime} 16^{\prime \prime} \mathrm{N}$ and $85^{\circ} 13^{\prime} 28^{\prime \prime} \mathrm{E}$ to $85^{\circ} 31$ '53'E. Kathmandu valley is Nepal's most densely populated area covering one metropolitan city, one sub metropolitan city, and three municipalities. It houses total population of 2,517,023 as per 2011 census. This valley has average elevation of $1350 \mathrm{~m}$ and enclosed between two peaks Shivapuri $(2732 \mathrm{~m})$ in the north and Mahabharat $(2765 \mathrm{~m})$. Kathmandu valley is primarily an alluvial deposit consisting of alluvial plains, lacustrine deposits. Groundwater occurring in Kathmandu valley is constituted by unconfined, semiconfined, and confined aquifers, as per the geologic formation Kathmandu valley groundwater occurrence is divided into three groundwater districts (Fig. 2.2); the northern groundwater district, central groundwater district, and the southern groundwater district [13]. Kathmandu basin consists of hard rock as a hydrological basement and unconsolidated soft sediments overlying the basement floorincludes gravel, sand, silt, clay, peat, and ignite brought from the surrounding hills in all direction. The groundwater system in Kathmandu valley is considered to be a closed and isolated ground water basin, with some interconnected aquifers. With due consideration of sediment nature, the northern and northeastern deeper parts $(>90 \mathrm{~m})$ of the central and southern parts fall under good aquifer zones, and the southern part of the valley consists of basal gravel bed overlying the basement rock with lateral continuity with less developed aquifer. The exact number of tube wells in Kathmandu valley is difficult to depict due to unrestricted access; moreover it is almost obvious that every household consists of at least one well; beyond this, industries, water supply corporation, hotels drag water in large quantity. The contribution of groundwater in supply of Kathmandu valley is almost about $50 \%$ of total supply [14]. The groundwater table previously is assumed to be lowered at the rate of $2.5 \mathrm{~m} /$ year [15].

The Kathmandu basin is an intermixed basin comprising up to $550 \mathrm{~m}$ of Pliocene-Quaternary fluvio-lacustrine sediments. The upper unconfined aquifer of Late Quaternary sand up to $20 \mathrm{~m}$ thick overlies an aquitard of black clay with peat and lignite bands. The aquitard is especially well developed on the western side of the valley, where it is up to 200 $\mathrm{m}$ thick. Beneath the aquitard is a sequence of Pliocene sand and gravel beds, intercalated with clay, peat and lignite. These sand and gravel beds collectively comprise a deeper, confined aquifer, which provides an important water supply to the central urban area of Kathmandu. Recharge to the upper aquifer is from direct infiltration of monsoonal rain and from stream flow on the north and east of the basin. The ba- 


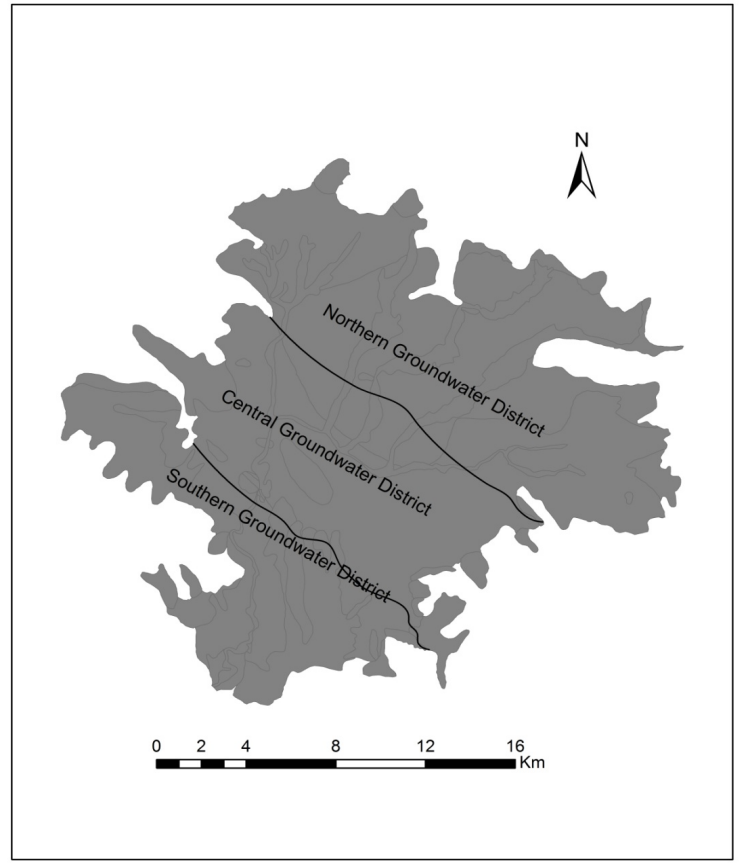

Fig. (2.2). The three groundwater districts in Kathmandu valley (after JICA, 1990).

sin has a superficial outlet through the gorge of the Bagmati River, in the southwest.

\section{DATA EXTRACTION}

The average static groundwater table data from year 2000 through 2005 were derived from Nepal Water Supply Corporation (NWSC), Melamchi Water Supply Development Board (MWSDB) Nepal and private drag wells data of various hotels and hospitals were acquired from Department of Hydrology and Meteorology (DHM), Nepal (Table 1). There is no regular monitoring mechanism for groundwater, so the periodic data acquisition is not possible in Kathmandu valley. Unrestricted access to pumping has given rise to increased drawdown in recent dates, though there is no any record of such abstraction. Till date, each and every Kathmandu valley houses have their own drag wells, and in every 2-3 years, 2-3 rings (about 1.5-2 $\mathrm{m}$ ) for drag wells are to be added for abstracting groundwater, as the household level groundwater abstraction is never monitored, though people usually add 2-3 rings in every 2-3 years; delineating an alarming rate of drawdown, but record of such drawdown is seldom available in Nepal. Most of the hotels abstract groundwater in large quantity, moreover, public and private sector companies which supply water for household level, hotels and other agencies is beyond the monitoring mechanism, hence exact quantity of groundwater abstraction is impossible to delineate. Groundwater in Kathmandu valley is available in unconfined, semi-confined and confined aquifers in shallow aquifers with poor recharge condition, thus rapid drawdown in groundwater table is leading to the severely water scarce scenario. The deep tube wells, which are conducted by public as well as private sectors, have over-drafted groundwater however; the database is not available for such privately constructed wells.

\section{ANALYSIS OF GROUNDWATER DRAWDOWN}

The six year data have been fitted in linear regression model in MATLAB version in order to draw a representative drawdown equation for Kathmandu valley. The standard deviation range for each observation well has been calculated in order to identify the range of standard deviation for all of the observation wells. Finally, the drainage points have been marked and yearly drainage dynamics has been presented in Arc GIS version. The digital elevation model for the static groundwater table has been employed in depicting the drainage dynamics with two of the significant drainage points highlighted. All the data abstracted from various agencies were classified as per relevance and representative twenty five observation wells representing all three groundwater districts have been selected. The southern groundwater district doesn't incorporate many observation wells, so average static groundwater table depth of three significant wells have been taken for analysis. Each of the observation well has been analyzed depicting a regression model and averaged for obtaining the average annual drawdown pattern of groundwater table in Kathmandu valley.

\section{RESULTS AND DISCUSSIONS}

The lowering of groundwater table (Table 1) is found to be 2 to $10 \mathrm{~m}$ in the northern groundwater district in six years period, meanwhile for the central groundwater district it has been found to be less than $1 \mathrm{~m}$ to $10 \mathrm{~m}$ and for the southern groundwater district, groundwater is found to be almost constant. As this regression model, does not incorporate the annual recharge, precipitation, infiltration and other factors governing the groundwater table depth, one dimensional average drawdown pattern has been depicted as;

$$
y=-0.7249 x-z[0.283 \leq S D \leq 3.768
$$

Wherein, $y$ indicates the groundwater table depth after $\mathrm{x}$ years. The $\mathrm{z}$ value indicates the reference year groundwater table depth. The negative value has been employed for indicating the depth of groundwater table below the ground surface. Equation (1) indicates the average of $0.7249 \mathrm{~m}$ drawdown yearly with the standard deviation range of 0.283 to 3.768. Previously it was assumed to be $2.5 \mathrm{~m}$ yearly, however the records analyzed from 2000 through 2005 show that the average drawdown in Kathmandu valley to be far less than previously assumed. The drawdown pattern from each of the groundwater district shows the acceptable linear pattern, so linear regression model has been fit for drawdown pattern of Kathmandu valley (Fig. 5.1 (a), 5.1 (b), 5.1 (c)) for all three groundwater districts.

The yearly drainage dynamics depict the shifting towards southwest region of valley (Fig.. 5.2 (a), 5.2 (b), 5.2 (c), $\mathbf{5 . 2}$ (d), $\mathbf{5 . 2}$ (e), $\mathbf{5 . 2}$ (f)); indicating that the groundwater concentration is shifting towards the southwest part of Kathmandu valley from the central groundwater district; however the drainage of northern groundwater district is relatively stagnant.

The central groundwater district has the maximum drawdown in the observation period, as most of the urban population is concentrated over this and no other alternative water 
Table 1. Average static groundwater table depth $(\mathrm{m})$ in Kathmandu valley.

\begin{tabular}{|c|c|c|c|c|c|c|c|}
\hline \multirow{2}{*}{ Observation site } & \multirow{2}{*}{$\begin{array}{c}\text { Groundwater } \\
\text { District }\end{array}$} & \multicolumn{6}{|c|}{ Average static Groundwater table depth (m) } \\
\hline & & 2000 & 2001 & 2002 & 2003 & 2004 & 2005 \\
\hline Bansbari & NGD & 74.66 & 78.28 & 81.35 & 83.13 & 83.77 & 82.50 \\
\hline Gongabu & NGD & 20.99 & 24.08 & 27.44 & 29.33 & 30.64 & 29.27 \\
\hline Kapan & NGD & - & 2.53 & 2.51 & 2.64 & 3.14 & 3.35 \\
\hline Putung & NGD & - & 12.70 & 13.09 & 13.15 & 14.11 & 14.70 \\
\hline Mahankal & NGD & 29.83 & 30.33 & 29.42 & 30.27 & 31.95 & 31.85 \\
\hline Nayapati-6 & NGD & 13.38 & 19.30 & 20.32 & 22.71 & 22.43 & 23.73 \\
\hline Nayapati-2 & NGD & 24.95 & 26.82 & 27.66 & 25.82 & 24.89 & 20.33 \\
\hline Bhaktapur & NGD & 38.07 & 38.90 & 40.43 & 41.78 & 42.68 & 45.21 \\
\hline Duwakot & NGD & - & 92.50 & 92.01 & 92.83 & 93.76 & 95.23 \\
\hline Mulpani-1 & NGD & - & 33.30 & 32.01 & 32.92 & 33.54 & 36.33 \\
\hline Mulpani-2 & NGD & - & 33.10 & 31.75 & 33.70 & 34.31 & 35.24 \\
\hline Mulpani-3 & NGD & - & 31.80 & 30.81 & 32.91 & 34.25 & 34.14 \\
\hline Balaju-1 & CGD & 0.98 & 3.42 & 4.40 & 7.04 & 8.80 & 8.33 \\
\hline Balaju-2 & $\mathrm{CDG}$ & 13.08 & 13.74 & 14.87 & 15.57 & 18.26 & 19.11 \\
\hline Patan-1 & CGD & 10.78 & 10.82 & 10.40 & 10.06 & 10.56 & 10.66 \\
\hline Tripureshwor & CGD & 0.63 & 0.97 & 1.09 & 1.66 & 1.79 & 0.98 \\
\hline Baluwatar & CGD & 22.81 & 24.78 & 27.22 & 28.86 & 31.74 & 31.39 \\
\hline Durbarmarg & CGD & 19.36 & 19.98 & 20.44 & 21.58 & 22.41 & 24.34 \\
\hline Dhobighat & CGD & 7.60 & 7.50 & 7.61 & 7.41 & 7.76 & 8.26 \\
\hline Tahachal & $\mathrm{CDG}$ & 7.24 & 6.17 & 6.64 & 4.77 & 5.00 & 6.27 \\
\hline Naikap & CGD & 1.86 & 1.93 & 1.64 & 2.09 & 2.73 & 3.58 \\
\hline Patan-2 & CGD & 33.16 & 35.13 & 29.66 & 32.60 & 33.48 & 37.58 \\
\hline Taudaha & SDG & - & 7.97 & 7.92 & 7.41 & 6.95 & 7.94 \\
\hline Sunakothi & SDG & - & 28.11 & 26.17 & 23.61 & 21.04 & 19.70 \\
\hline Lubhu & SDG & - & 30.11 & 30.35 & 30.77 & 31.29 & 32.05 \\
\hline
\end{tabular}

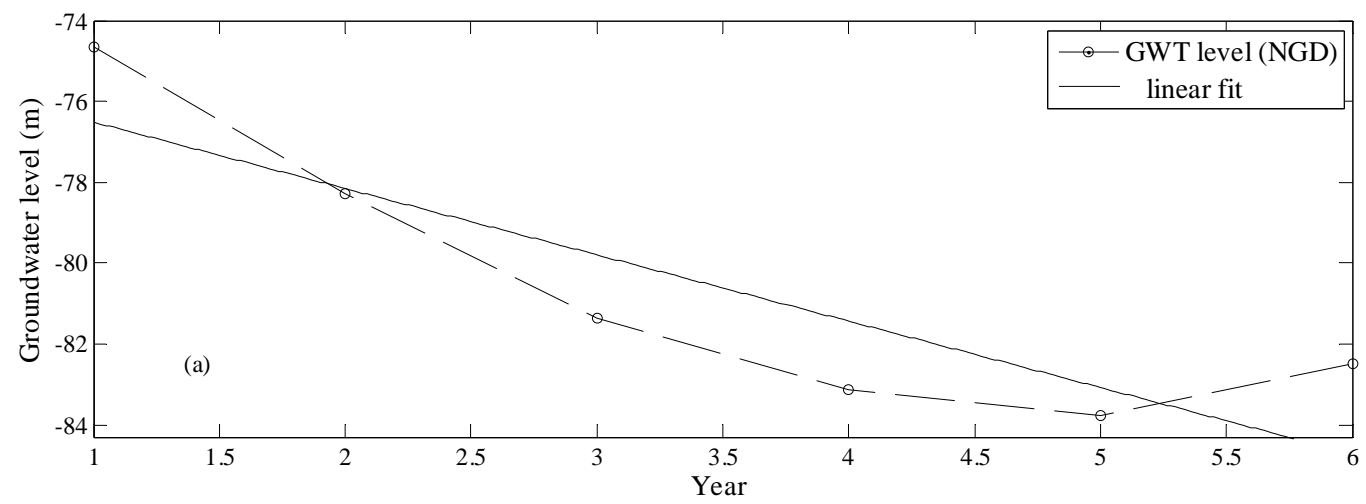

Fig. (5.1). (a) Groundwater table variation and linear fit (Bansbari) [1 indicates the base year 2000]. 


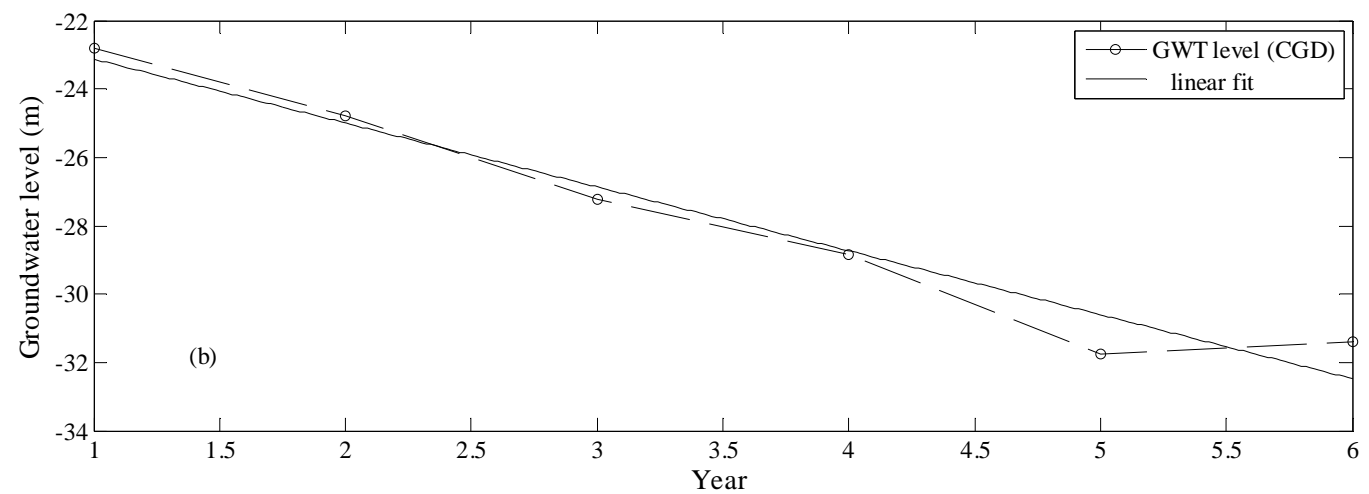

Fig. (5.2). (b) Groundwater table variation and linear fit (Baluwatar) [1 indicates the base year 2000].

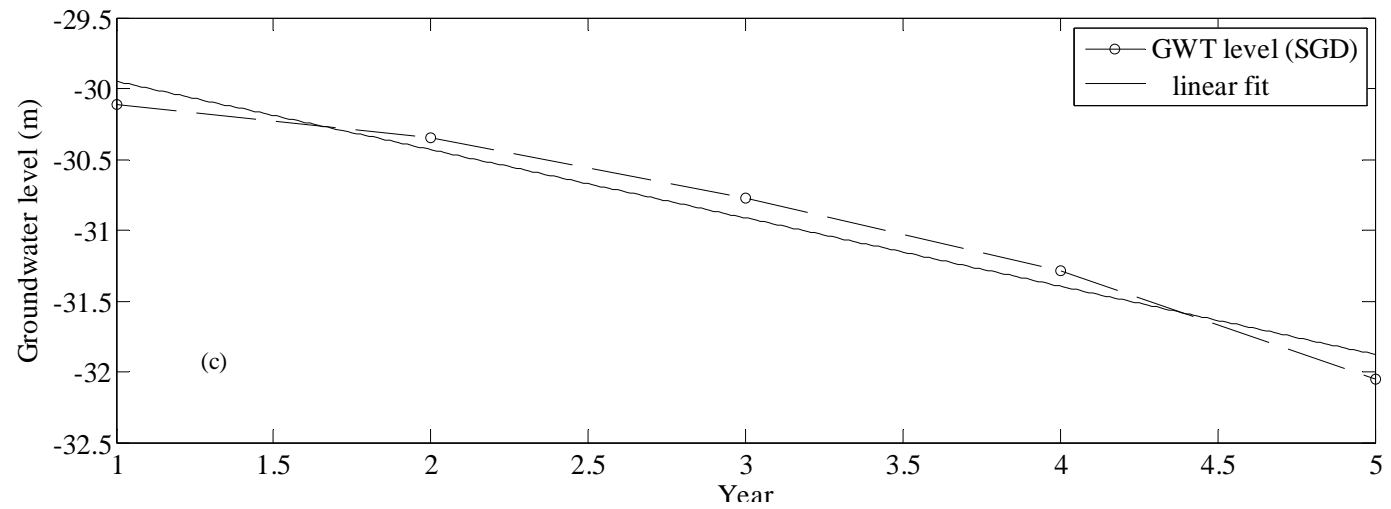

Fig. (5.2). (c) Groundwater table variation and linear fit (Lubhu) [1 indicates the base year 2000].

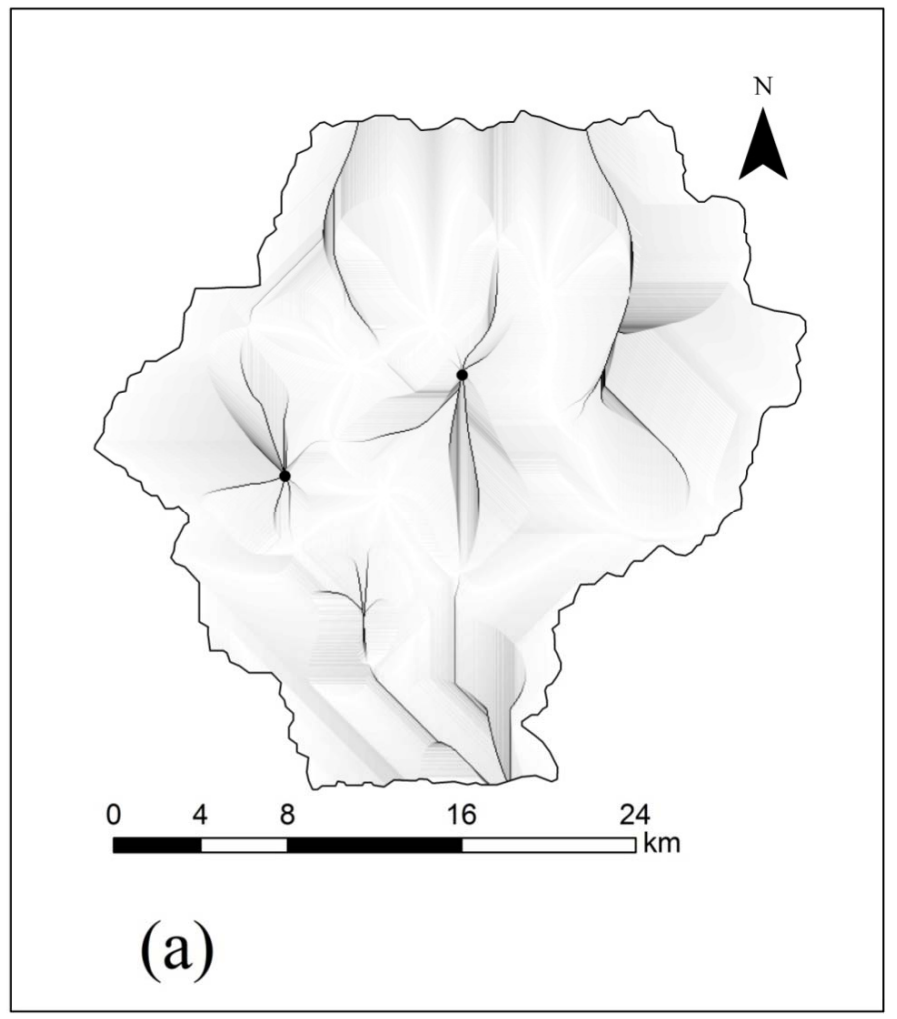

Fig. (5.2). (a) Drainage points, year 2000 . 


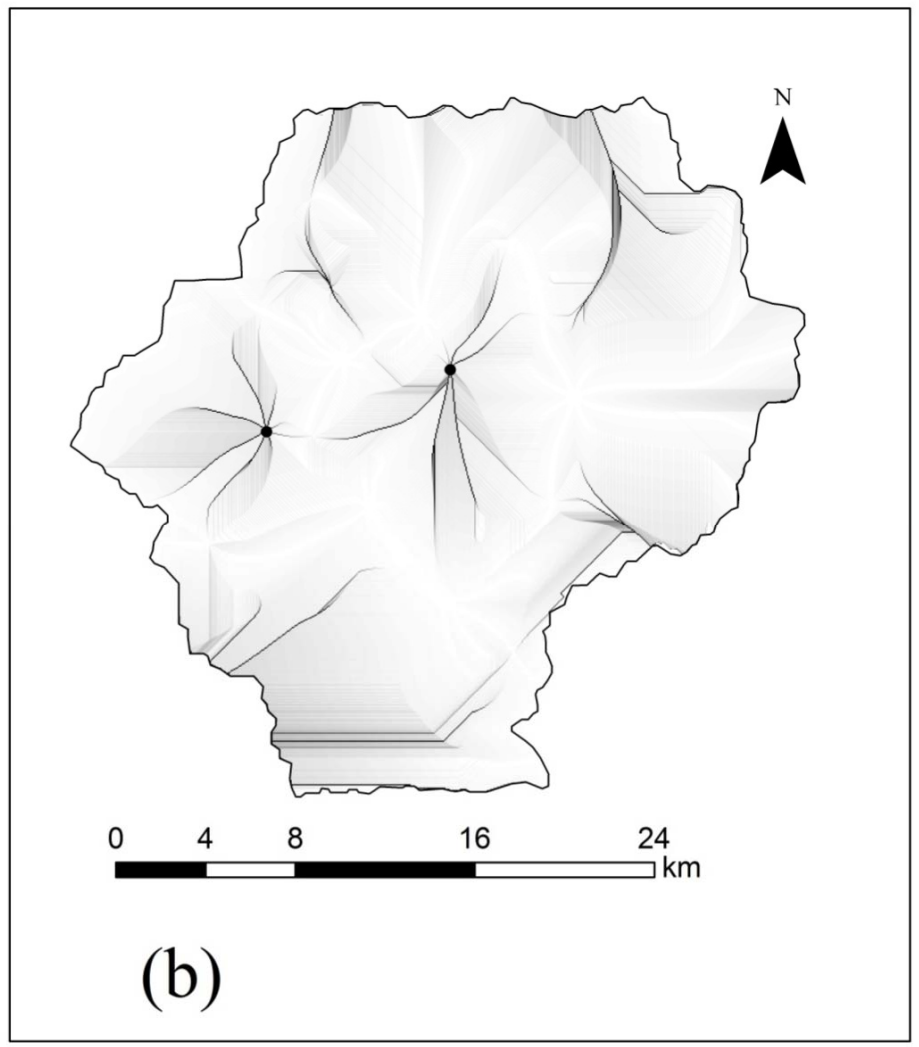

Fig. (5.2). (b) Drainage points, year 2001.

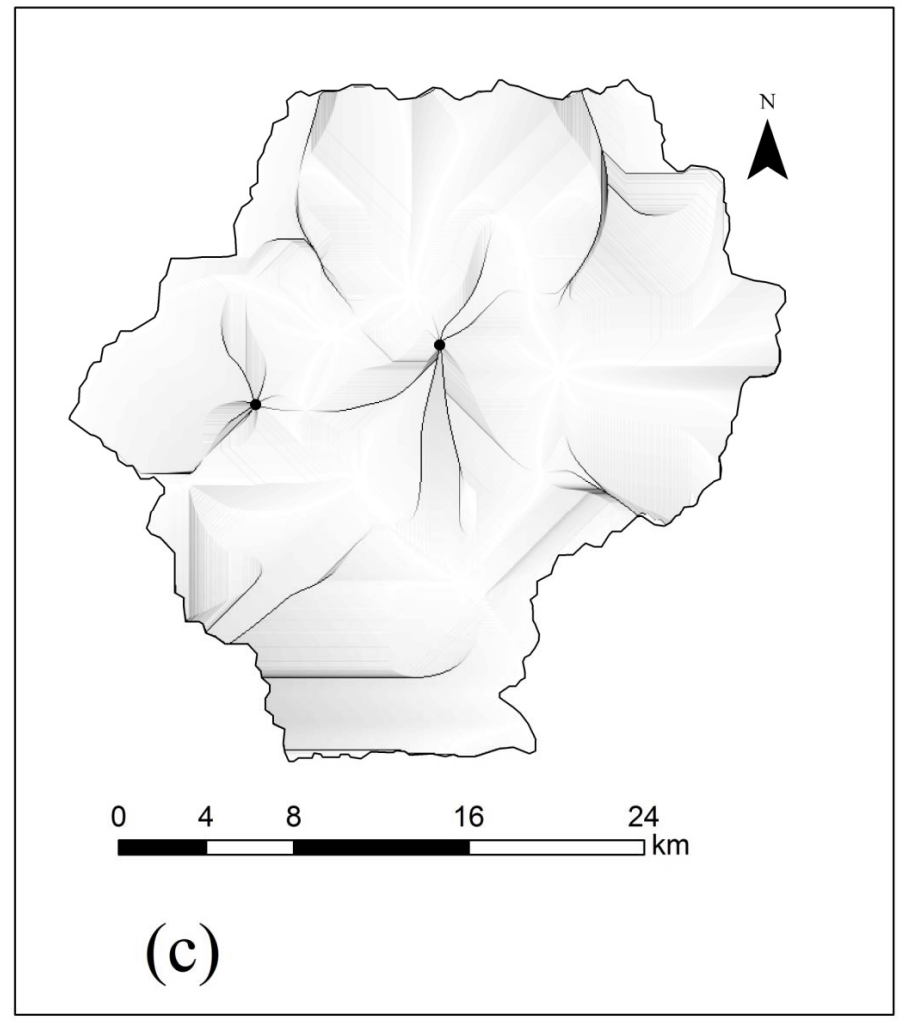

Fig. (5.2). (c) Drainage points, year 2002. 


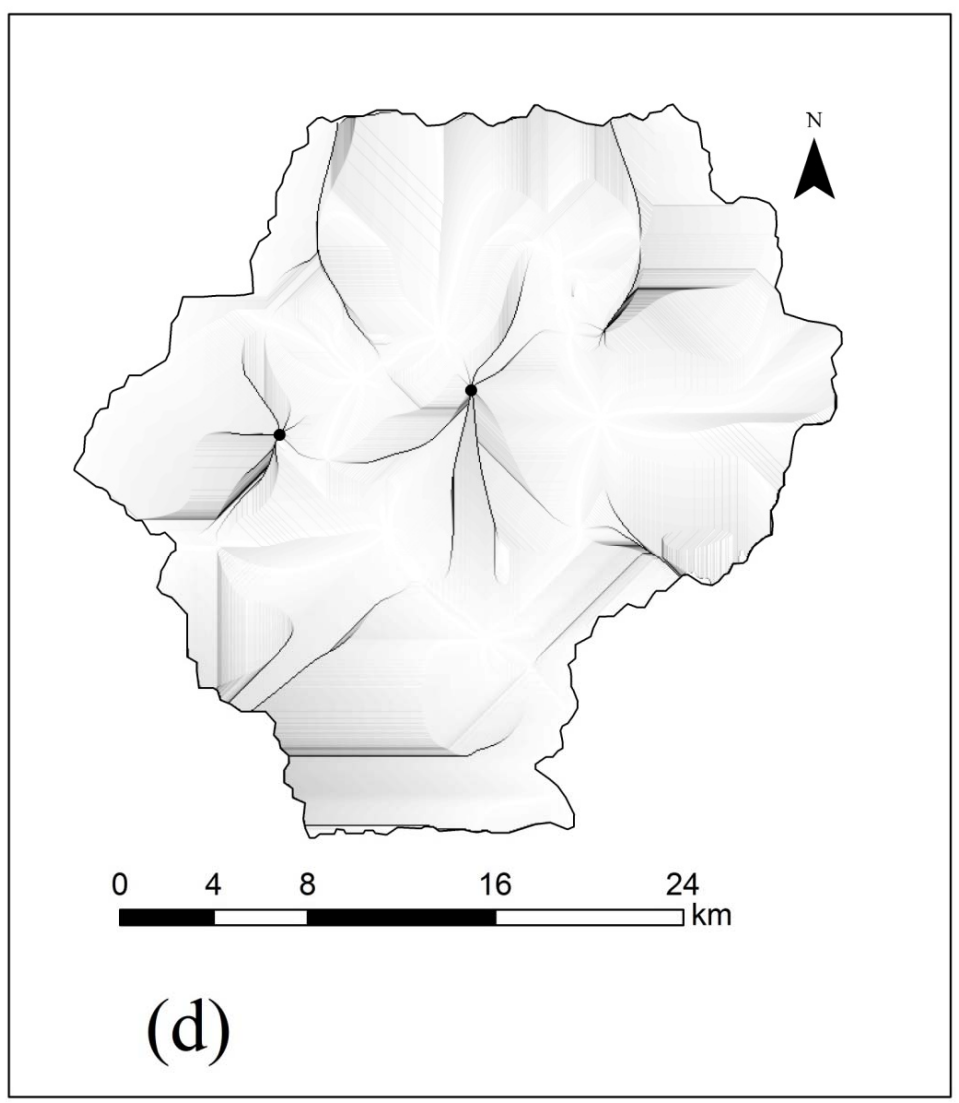

Fig. (5.2). (d) Drainage points, year 2003.

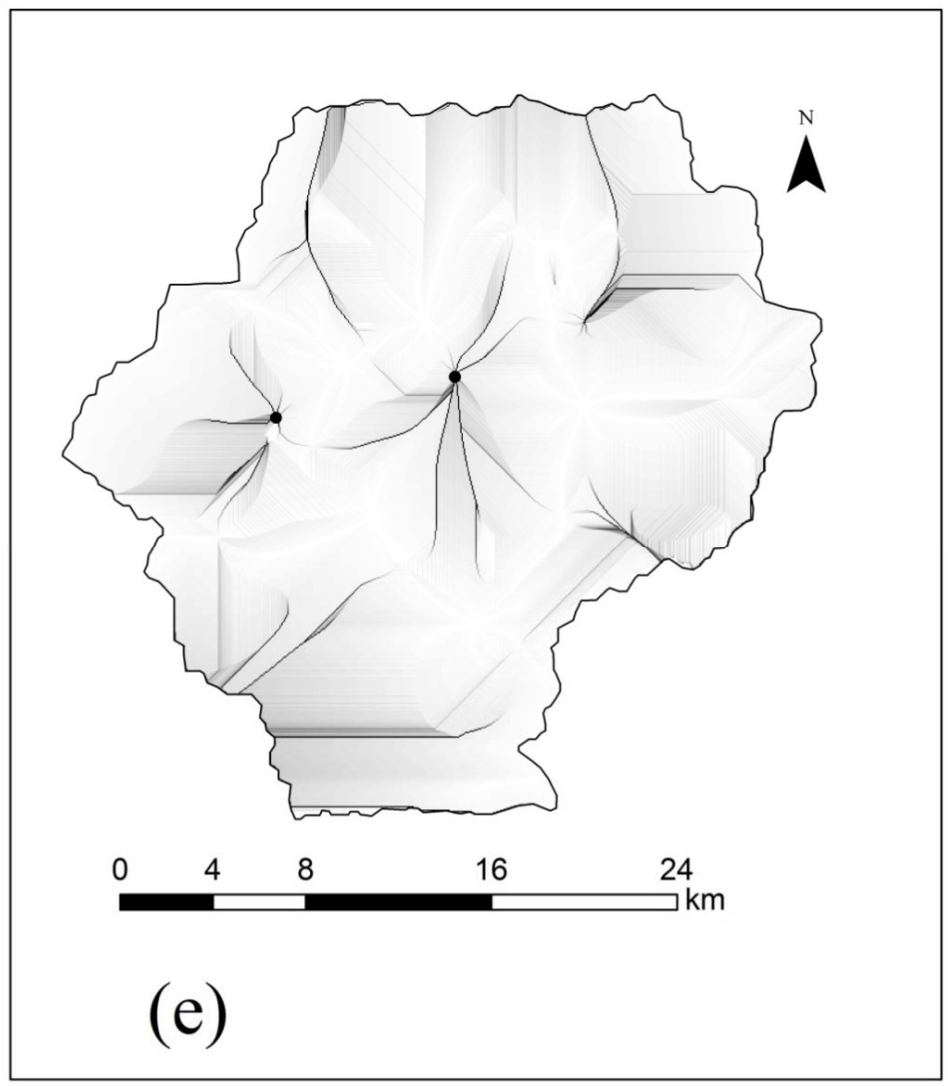

Fig. (5.2). (e) Drainage points, year 2004. 


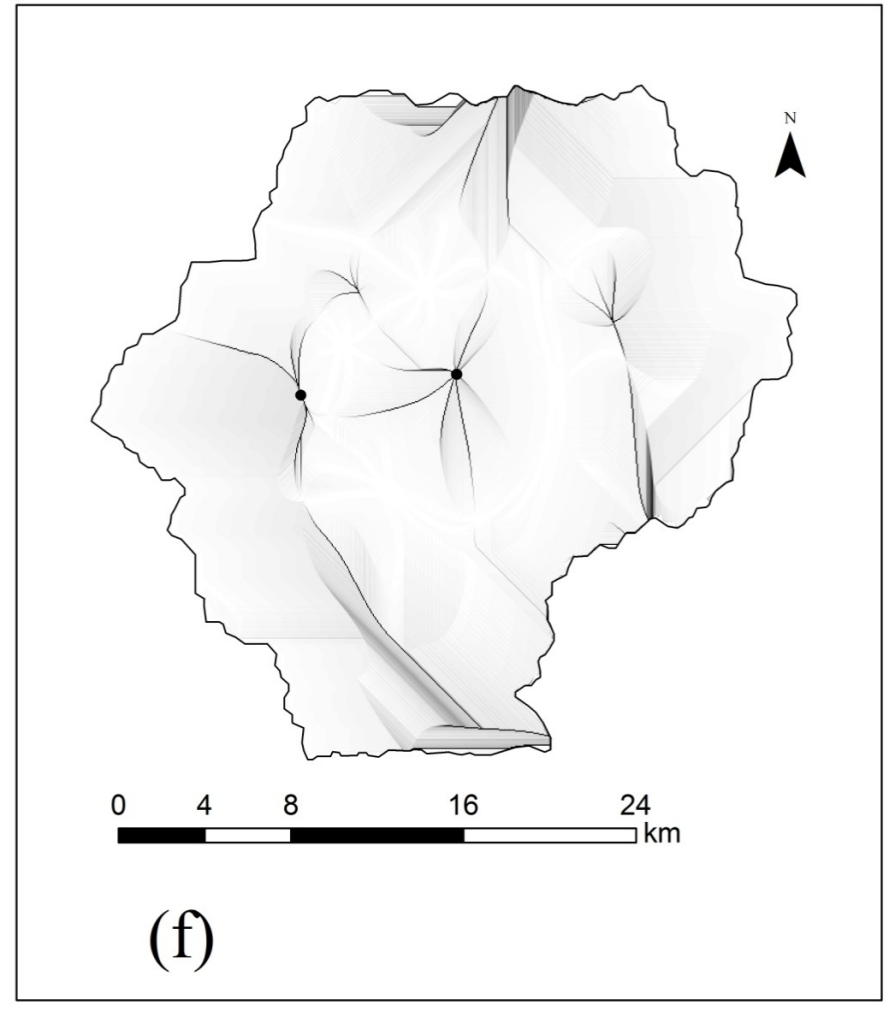

Fig. (5.2). (f) Drainage points, year 2005 .

supply source is available and entire population has been relying on the groundwater, so lowering of groundwater and rapid urbanization have been predicted to be correlated. As central groundwater district and southern groundwater districts are not capable of recharging, the alarming rate of groundwater abstraction might cause severe hydrogeological problems herein, the depletion of aquifer zone may lead to land subsidence, soil moisture change, among others. Till date, there are some crop fields in the periphery of Kathmandu valley i.e. in the northern and southern groundwater district, however, recent trend of land use change, and urbanization has even diminishing such arable lands leading to enhanced built up area, removal of vegetation and degraded recharge zones.

Average rainfall in Kathmandu valley is taken as 1755 $\mathrm{mm}$, of which around $80 \%$ occurs during June through September [8]. The average groundwater level contribution seems to be varied by $0.7249 \mathrm{~m}$ per year, however during dry season, groundwater level is found to be lowered by greater extent hence water scarcity in every household is severe during dry season. This leads to increased demand in water supply from the companies which usually abstract water from deep tube wells and distribute in household level. Sustainable groundwater abstraction planning has not been functional yet in Kathmandu valley, so the storage might conclude soon, leading in several hydrological, hydro-geological and environmental impacts. Most of the rainwater drains as surface flow, and there are no potential recharge areas as well. Previously the northern groundwater district was believed to be the potential recharge zone; however, the anthropogenic encroachment, land use change, concrete structure construction, and urbanization in this district have led the diminishing vegetative cover and arable land so that infiltration has been ever decreasing leading to a devastating scenario of groundwater recharge. The major aquifer zone in the Kathmandu valley is constituted by the northern groundwater district, and the present trend of urbanization in this region along with the overexploitation for pumping supply in Kathmandu valley is putting pressure in this region largely. Nowadays, most of the valley households rely on the pumped water supply through various private sectors, and most of the pumping wells are concentrated in the northern and southern groundwater districts along with the brick factories, contributing the overdraft and groundwater pollution. As there is no any alternative resource of groundwater, the mushroomed population concentration, factories and hotels are needed to be supplied through groundwater.

The severity of drawdown in groundwater could be controlled through effective groundwater management. Household level recharge and rainwater harvesting, replenishment of groundwater during monsoon, storing the monsoon water for dry season use, zoning of urban areas and land use planning, reforestation, conservation of potential recharge zones, shifting the factories and hotels or bringing into the revenue criteria could be effective in groundwater management and planning. Policy level clarity regarding the abstraction and recharge of groundwater is needed so as to control the unrestricted business in groundwater overexploitation. Regular monitoring of groundwater table, proper modeling and researches would be effectively used for sustainable 
abstraction of groundwater resources in order to avoid ground subsidence, pollution of groundwater, and even planning the replenishment works. Brick factories, hotels and private water supply companies are primarily responsible for overexploitation and pollution of groundwater resources in Kathmandu valley, so primary focus during groundwater management is to be paid for these. Preventing the sewer networks from reaching upto the natural water courses, and avoiding pollution to surface resources could lower pressure and pollution in groundwater, ultimately lowering the exploitation as well.

\section{CONCLUSION}

Due to the concentration of anthropogenic activities, rapid concretization and urbanization, over-drafting of groundwater, low recharge scenario, removal of vegetation, unrestricted exploitation of groundwater resources, haphazard land use practice, overdraft by the hotels and factories among others groundwater in Kathmandu valley is declining at an alarming rate, indicating a severe water scarcity in future. However, the drawdown is uneven across the valley; a representative linear regression model has been presented along with the range of standard deviation and the rate has been depicted as $0.7249 \mathrm{~m}$ annual drawdown in average a comparable value as that of alluvial valley of Mexico City where the drawdown has been variously reported as $1 \mathrm{~m}$ annually in average. While Mexico City has been facing land subsidence problem these days, so for an alluvial intermontane basin of Kathmandu, similar problems would be inevitable but there is no significant research in this dimension. Present day water scarcity has been well represented through the drawdown of groundwater table in Kathmandu valley, thus concluding the central groundwater district is facing the highest rate of drawdown. The northern groundwater district has relatively less drawdown rate, it is due to less population density, potential recharge zone lying here, and even the good vegetation cover as well, however recent trend in this region is also altered along with the urbanization, water supply companies, and removal of vegetation cover. Low permeability in the central and southern groundwater districts are also contributing in the rapid drawdown, however, the northern groundwater district is composed of relatively permeable sediments thus facilitating the recharge as well. Concentration of population in central groundwater district is the highest compared to any other parts of Nepal, because this district constitutes the only metropolitan city and one submetropolitan city as well, thus increased water demand has triggered the overexploitation from household to hotel level. The annual dynamics of groundwater table has been found to be shifting towards the southwestern region of Kathmandu valley. As the water table in northern groundwater table is relatively stagnant with regard to discharge, the central groundwater is contributing in the discharge dynamics thus being shifted towards the southwestern region.

\section{ABBREVIATIONS}

$\mathrm{ADB}=$ Asian Development Bank
$\mathrm{CGD}=$ Central groundwater district

DHM = Department of Hydrology and Meteorology, Government of Nepal

GIS = Geographical Information System

HMG = His Majesty's Government of Nepal

JICA = Japan International Cooperation Agency

MLD = Million liters per day

MPPW $=$ Ministry of Physical Planning and Works, Government of Nepal

NGD $=$ Northern groundwater district

SDG = Southern groundwater district

$\mathrm{SD}=$ Standard deviation

SMEC $=$ Snowy Mountains Engineering Corporation

\section{CONFLICT OF INTEREST}

The authors confirm that this article content has no conflict of interest.

\section{ACKNOWLEDGEMENTS}

The authors are grateful to the Nepal Water Supply Corporation (NWSC), Melamchi Water Supply Development Board (MWSDB), Department of Hydrology and Meteorology (DHM), Nepal for their cooperation in obtaining the average groundwater table depth of many locations.

\section{REFERENCES}

[1] Bradley C. Simulation of the annual water table dynamics of a floodplain wetland Narborough Bog, UK. J Hydrol 2002; 261: 15072.

[2] Winter TC. Relation of streams, lakes and wetlands to groundwater flow systems. Hydrogeol J 1999; 7: 28-45.

[3] Shah T, Indu R. Fluorosis in Gujarat: A Disaster Ahead. IWMITata Program Annual Partner's Meet, Anand. 2004.

[4] Metcalf and Eddy. Urban water supply reforms in the Kathmandu valley (ADB-TA); Report No.: 2998-NEP 2000.

[5] Stanley International Ltd. The Bagmati Basin water management strategy and investment program. Report to Nepal Ministry of Housing and Physical Planning, Nepal: Government of Nepal. 1994.

[6] Binnie and Partners. Water supply for Kathmandu-Lalitpur from outside the Valley. Kathmandu, Nepal. 1998.

[7] Gautam R, Rao GK. Groundwater resource evaluation of the Kathmandu Valley. J Nepal Geol Soc 1991; 7: 39-48

[8] Pandey VP, Chapagain SK, Kazama F. Evaluation of groundwater of Kathmandu Valley. Environ Earth Sci 2010; 60: 1329-42.

[9] HMG. Optminizing water use in Kathmandu Valley (ADB-TA) Project. Final Report. Nepal: Ministry of Physical Planning and Works. Kathmandu, 2004.

[10] Cresswell RG, Bauld J, Jacobson G, et al. A first estimate of ground water ages for the deep aquifer of the Kathmandu Basin, Nepal, using the radioisotope chlorine-36. Ground Water 2001; 39: 449-57.

[11] SMEC. Greater Kathmandu Water Supply Project. Final Report, Volume 3. Hydrology, November. 1992.

[12] Dingman SL. Physical Hydrology. UK: Macmillan, 2002.

[13] JICA. Groundwater management project in the Kathmandu Valley, 1990, Final Report to Nepal water supply cooperation. Japan: Japan International Cooperation Agency (JICA)/Environment and Public Health Organization (ENPHO), Arsenic vulnerability in groundwater resources in Kathmandu Valley 2005. 
[14] Jha MG, Khadka MS, Shrestha MP, Regmi S, Bauld J, Jacobson G. The assessment of groundwater pollution in the Kathmandu Valley. Nepal: report on Joint Nepal-Australia Project 1995-96. Australian Geological Survey Organization, Canberra 1997.
[15] MPPW. Optimizing water use in Kathmandu valley project. Nepal: Government of Nepal 2002.

Received: June 23, 2014

Revised: August 18, 2014

Accepted: August 30, 2014

(C) Gautam and Prajapati; Licensee Bentham Open.

This is an open access article licensed under the terms of the Creative Commons Attribution Non-Commercial License (http://creativecommons.org/licenses/by-nc/3.0/) which permits unrestricted, non-commercial use, distribution and reproduction in any medium, provided the work is properly cited. 